\title{
Homage to Hersteinsson and Macdonald: climate warming and resource subsidies cause red fox range expansion and Arctic fox decline
}

\author{
Bodil Elmhagen ${ }^{a}$, Dominique Berteaux ${ }^{b}$, Robert M. Burgess ${ }^{c}$, Dorothee Ehrich ${ }^{d}$, Daniel Gallant ${ }^{b, e, f}$, \\ Heikki Henttonen ${ }^{\text {, }}$ Rolf A. Ims ${ }^{d}$, Siw T. Killengreen ${ }^{d}$, Jukka Niemimaa ${ }^{g}$, Karin Norén ${ }^{a}$, Tuomo Ollila ${ }^{h}$, \\ Anna Rodnikova', Aleksandr A. Sokolov', Natasha A. Sokolovaj, Alice A. Stickneyk \& Anders Angerbjörna
}

aDepartment of Zoology, Stockholm University, Stockholm, Sweden; ${ }^{b}$ Canada Research Chair on Northern Biodiversity and Centre for Northern Studies, Université du Québec à Rimouski, Rimouski, Canada; 'ABR, Inc. - Environmental Research and Services, Fairbanks, AK,

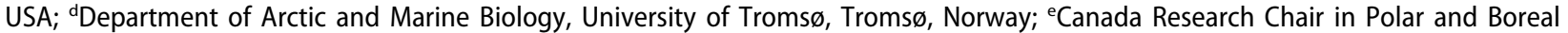

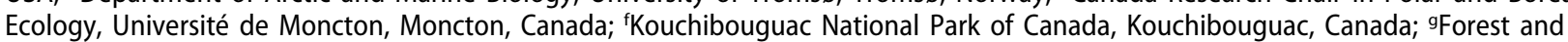

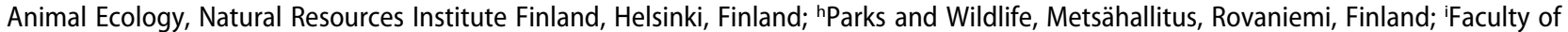
Biology, Lomonosov Moscow State University, Moscow, Russia; 'Science Center for Arctic Studies (State Organization of Yamal-Nenets Autonomous District) and Arctic Research Station of Institute of Plant and Animal Ecology, Ural Branch of Russian Academy of Sciences, Labytnangi, Russia; ${ }^{k}$ Ester, AK, USA

\section{ABSTRACT}

Climate change can have a marked effect on the distribution and abundance of some species, as well as their interspecific interactions. In 1992, before ecological effects of anthropogenic climate change had developed into a topical research field, Hersteinsson and Macdonald published a seminal paper hypothesizing that the northern distribution limit of the red fox (Vulpes vulpes) is determined by food availability and ultimately climate, while the southern distribution limit of the Arctic fox (Vulpes lagopus) is determined by interspecific competition with the larger red fox. This hypothesis has inspired extensive research in several parts of the circumpolar distribution range of the Arctic fox. Over the past 25 years, it was shown that red foxes can exclude Arctic foxes from dens, space and food resources, and that red foxes kill and sometimes consume Arctic foxes. When the red fox increases to ecologically effective densities, it can cause Arctic fox decline, extirpation and range contraction, while conservation actions involving red fox culling can lead to Arctic fox recovery. Red fox advance in productive tundra, concurrent with Arctic fox retreat from this habitat, support the original hypothesis that climate warming will alter the geographical ranges of the species. However, recent studies show that anthropogenic subsidies also drive red fox advance, allowing red fox establishment north of its climate-imposed distribution limit. We conclude that synergies between anthropogenic subsidies and climate warming will speed up Arctic ecosystem change, allowing mobile species to establish and thrive in human-provided refugia, with potential spill-over effects in surrounding ecosystems.
KEYWORDS

Climate change; range shift; resource subsidy; mesopredator release; Vulpes lagopus; Vulpes vulpes

\section{ABBREVIATIONS}

BP: British Petroleum; IUCN: International Union for Conservation of Nature and Natural Resources

\section{Introduction}

The Earth's climate system is warming and there is high confidence that this has caused many species to shift their geographic ranges and local abundances (Parmesan \& Yohe 2003; IPCC 2014). In the Arctic, the rate of warming has been higher than the global average, with increasing temperatures in particular from 1900 to the mid1940s and after the mid-1960s (McBean et al. 2005). Climate warming in the Arctic has, for example, prolonged the growing season for plants, changed the phenology, demography and dynamics of several species, and led to a northern advance of shrubs, trees and some animals (Post et al. 2009; CAFF 2013). In 2009, the IUCN appointed a small Arctic carnivore, the Arctic fox (Vulpes lagopus, syn. Alopex lagopus), as one of 10 flagship species for climate change. The abundance and distribution range of the Arctic fox is expected to decline in response to climate warming, because of competition from an expanding southern competitor, the red fox (Vulpes vulpes; IUCN 2009). The importance of red fox competition as a climate-induced driver of Arctic fox decline was proposed before ecological effects of anthropogenic climate warming developed into a mainstream research field, but it presented a topical hypothesis on the fate of Arctic ecosystems in this era of climate change. The paper in question, Hersteinsson \& Macdonald (1992), has 162 citations in Web of Science and is still typically cited five or six times per year. Although many of the citing papers concern Arctic and red foxes (37\%), or relationships between carnivore species (19\%), several citations address broad topics such as climate change and conservation (23\%) or competition and predation (21\%). This demonstrates how Hersteinsson \& Macdonald (1992) pinpointed generally important effects of climate 
change on species distributions and a potential underlying mechanism regarding changing species interactions. Here we present the original hypothesis, review research carried out since it was published, and discuss the hypothesis in an updated scientific context pertaining to the ecological outcomes of changes in bottom-up processes related to climate warming and changing species interactions.

The Hersteinsson/Macdonald hypothesis on interspecific competition between Arctic and red foxes was first presented in Hersteinsson's PhD thesis (1984), and then developed into the well-cited seminal paper by Hersteinsson \& Macdonald (1992). The rationale behind the hypothesis is as follows. The red fox is the only fox species that occurs sympatrically with the Arctic fox in parts of its circumpolar distribution range. Although a red fox weighs $60 \%$ more than an Arctic fox in similar latitudes, both species are opportunistic carnivores that prey on small-to-mediumsized animals, suggesting that they compete for resources (Hersteinsson \& Macdonald 1982). Hersteinsson \& Macdonald (1992) argued that the red fox has inferior physical adaptations to cold climates, and that this, in addition to its larger size, leads to higher food requirements compared to the Arctic

(a) Hersteinsson \& Macdonald (1992)

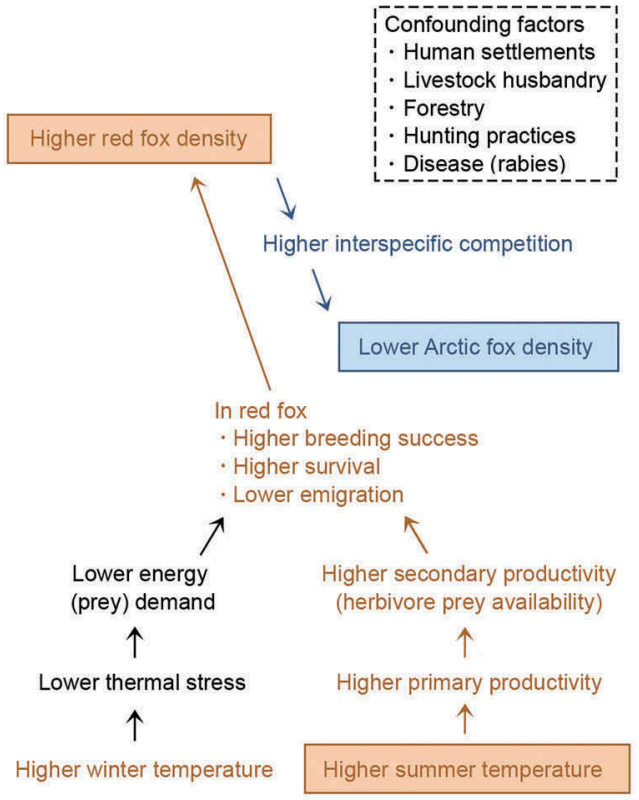

fox. This could be problematic for the red fox in Arctic habitats, assuming that harsh climate conditions are linked to low primary productivity which in turn is linked to low vertebrate abundance (i.e., prey availability). On the other hand, Hersteinsson \& Macdonald reviewed literature showing that larger carnivores tend to dominate over smaller ones in physical interactions, including primarily anecdotal observations of red foxes chasing or killing Arctic foxes. Based on this they argued that red foxes dominate Arctic foxes (Fig. 1a). Hence, Hersteinsson \& Macdonald (1992) hypothesized (1) that the northern and high-altitudinal distribution limit of the red fox is determined by prey availability and ultimately climatic conditions; and (2) that the southern and lowaltitudinal distribution limit of the Arctic fox is determined by interspecific competition with the red fox.

Hersteinsson \& Macdonald (1992) used a combined approach of data analysis and literature review to explore their hypothesis and its implications. Their analyses of historic fox hunting bags revealed that the proportion of Arctic fox pelts declined with increasing July temperatures, from the High Arctic into the boreal forest, in northeastern and central Canada. Over time, the

\section{(b) This review (2017)}

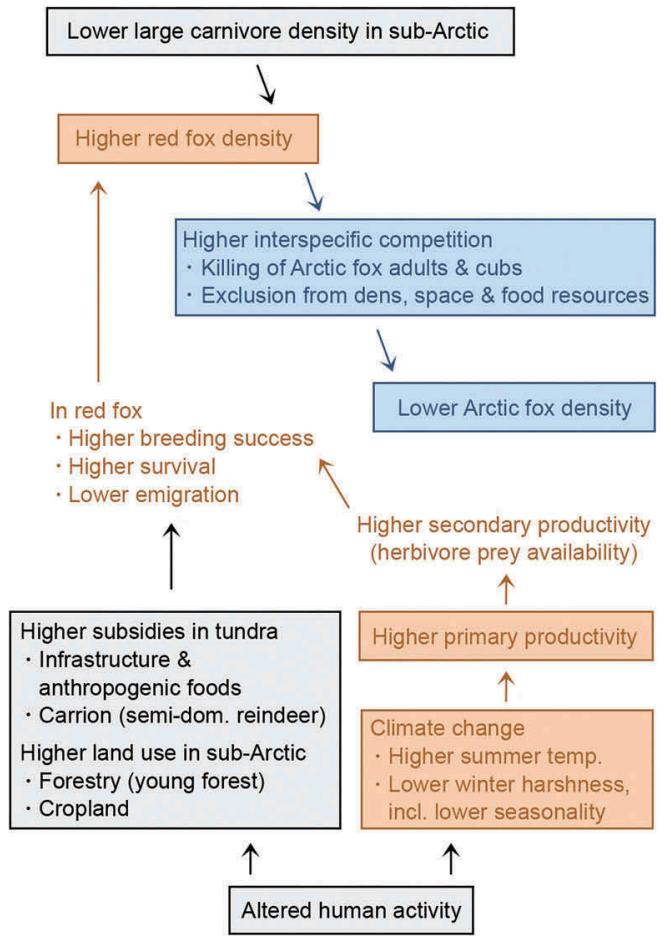

Figure 1. (a) Hersteinsson \& Macdonald (1992) showed that summer temperature, red fox density and Arctic fox density (boxes) were significantly associated. For the Arctic fox, they suggested that the negative effect of red fox competition would outweigh the positive effect of higher food availability. (b) This review supports these relationships (boxes), as well as some assumed ones (without boxes). Mechanisms linking increased red fox densities in the tundra to drivers of change, such as increased subsidies and primary productivity, remain poorly studied. Orange and blue colours in (a) and (b) indicate factors included in both maps. In (a), the dashed-line frame contains confounding factors listed by Hersteinsson \& Macdonald, who cautioned that they might also affect red fox density. Note that some of these are included in (b). However, it is not known whether, or to what extent, drivers associated with red fox density primarily in the sub-Arctic (forestry, agriculture, larger carnivores) also affect red foxes in the tundra, directly or indirectly. 
proportion of red fox pelts increased locally at the expense of Arctic fox pelts, in particular in 1920-1940. The review part of the paper showed that atmospheric temperatures and, presumably, primary productivity increased in 1880-1940. In the latter part of the period, red foxes established and spread north on Baffin Island in Canada, while the Arctic fox population in Fennoscandia plummeted (Hersteinsson \& Macdonald 1992). The rapid decline of Arctic fox in the alpine tundra of Fennoscandia in the early 1900s has generally been attributed to over-harvesting (Hersteinsson et al. 1989). However, Hersteinsson \& Macdonald (1992) argued that an altitudinal advance in summer temperature isotherms in the early 1900s could have caused a two-thirds loss of Arctic fox habitat, contributing to the decline of the Fennoscandian Arctic fox population. They pointed out that this also could explain why it did not recover after gaining protection status in most parts of Fennoscandia as soon as $1928-1940$.

Hersteinsson \& Macdonald (1992) were mindful of the dangers and limitations of inferring causation from correlative evidence, and they discussed alternative factors that changed together with climate during their study period. Nevertheless, their arguments on processes were either lacking in empirical evidence on the assumed bottom-up chain effect from climate warming to ecosystem secondary productivity (i.e., red fox prey availability) or were based on primarily anecdotal evidence related to fox interspecific interactions (Fig. 1a). This opened up possibilities for additional research as well as alternative hypotheses. For example, Bartoń \& Zalewski (2007) suggested that red fox density is limited by winter conditions and seasonality, rather than summer temperature and summer productivity, and that the negative effects of winter conditions and seasonality are mediated by the ability of the red fox to cope with harsh abiotic conditions, a short reproductive season and low prey availability. With regard to red fox range expansion, both Hersteinsson \& Macdonald (1992) and Bartoń \& Zalewski (2007) suggested that red foxes are favoured by climate warming, but alternative hypotheses propose that red foxes are favoured by anthropogenic resource subsidies (Selås et al. 2010; Gallant 2014), that they have adapted to northern climate conditions (Macpherson 1964), and specifically for North America, that the northern expansion was caused by the introduction of individuals from Eurasia which were better adapted to northern climates than native North American ones (Kamler \& Ballard 2002).

In this review, we summarize the support for the Hersteinsson/Macdonald hypothesis with respect to recent findings on (1) factors limiting/favouring red foxes and observed red fox expansions; (2) concurrent changes in the ranges and population trends of Arctic and red foxes; (3) Arctic and red fox interactions in areas where Arctic fox populations are stable; and (4) red fox effects on Arctic fox mortality, reproduction and behaviour. Since Hersteinsson \& Macdonald (1992) was published, most research on Arctic and red foxes has been carried out within the study areas of the authors of this review. Our aim was therefore to contrast Arctic and red fox interactions in these areas, which represent different settings within the circumpolar distribution range of the Arctic fox.

\section{Methods}

We reviewed research carried out on Arctic and red fox interactions and their demographic consequences for Arctic fox survival, reproduction and population trends since the publication of Hersteinsson and Macdonald (1992). Most research on Arctic and red foxes after 1992 has been carried out in study areas where we, the authors of this review, have worked (Fig. 2). To conduct this review, each research group provided a review of findings about the status of Arctic and red foxes in their study area, specifically on observed changes in fox distributions and abundance, potential drivers of these changes, as well as observed interspecific interactions and their consequences.

To ensure that we included all relevant publications, we also did a complementary literature search in Web of Science (including all databases) on 22 July 2016. The search was done on the string 'Vulpes lagopus' OR 'Alopex lagopus' AND 'Vulpes vulpes', with the time period set to 1992-2016. The search generated 291 papers. Based on titles and abstract, 33 of these fulfilled our criteria for inclusion, that is, the paper's results section presented an original statistical data analysis or field observations which provided information relevant for at least one of the subject areas in this review. All but two papers (Bailey 1992; Anthony 1996) were from our study areas. In addition to the 33 papers, the results section includes references to studies that were in press or in preparation when the literature search was done, as well as references to other publications which in our opinion contribute relevant information (grey literature and scientific papers).

Below we briefly present the study areas, where most field-based research on Arctic and red foxes has been carried out since 1992 .

\section{Fennoscandia}

The Arctic fox population mainly inhabits the Scandes, a high-altitude mountain range which is a southern extension of Arctic tundra spanning northernmost Finland, north-western Sweden and Norway. The 


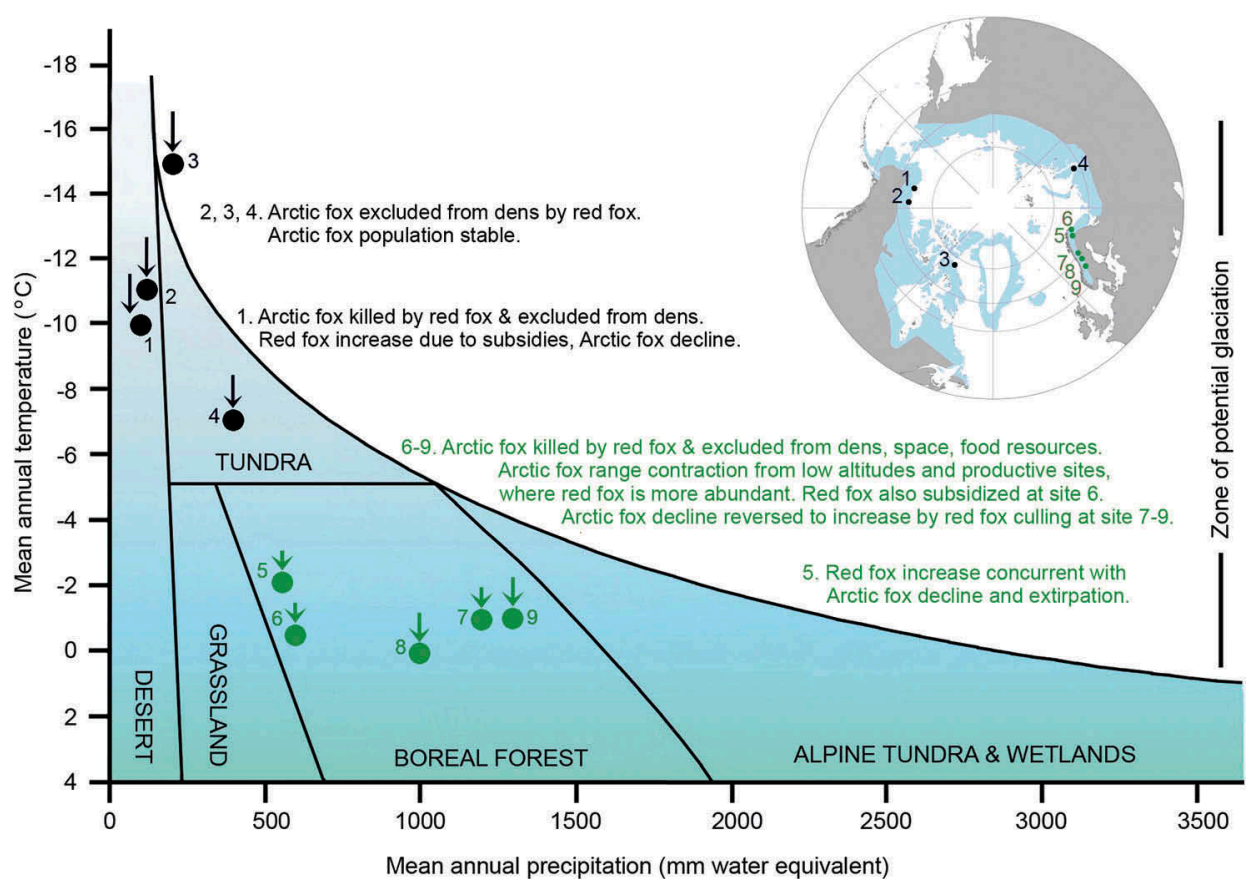

Figure 2. Observed interspecific interactions and population effects on the Arctic fox at different sites. In the graph, site locations are plotted in the temperature-precipitation environmental space (modified from Elger et al. 2012; Berteaux et al. 2017; data for Bylot Island from Zhang et al. 2013). The arrows indicate the estimated minimum increase in mean annual temperature since 1901 according to the IPCC (2014). Despite increased temperatures, the climate remains characteristic of tundra in black-marked sites. Sites marked green are located in Fennoscandia, where climate conditions are marginal for the Arctic fox (although the placing of the sites in the boreal forest likely also reflects that the temperature-precipitation space is not sufficient to determine biomes). In the inset map, the blue area indicates the circumpolar distribution range of the Arctic fox (modified from Berteaux et al. 2017). The sites are: 1, Prudhoe Bay; 2, Northern Yukon; 3, Bylot Island; 4, South Yamal; 5, Finnish Lapland; 6, Varanger; 7, Vindelfjällen; 8, Borgafjäll; 9, Helags.

Arctic fox also inhabits a small section of low-Arctic shrub tundra at the north-eastern tip of Norway (including Varanger Peninsula; Ims et al. 2017), where tundra habitats extend down to sea level. The entire range of the Fennoscandian tundra is fragmented by forested valleys, which create substantial contact zones with the boreal forest (Herfindal et al. 2010). The Arctic fox was abundant in the 19th century, but declined rapidly during extensive harvest in the early 20th century, and did not recover to previous levels following protection in Sweden (1928), Norway (1930) and Finland (1940), although in Finnish Lapland, the population was at moderate levels from 1940 until the early 1980s (Hersteinsson et al. 1989; Kaikusalo \& Angerbjörn 1995; Kaikusalo et al. 2000). The population was close to extinction in 1998-2000, when surveys of all known dens suggested a total population size of approximately 50 individuals (Angerbjörn et al. 2013). Since the 1980s, scientists from Fennoscandia have been involved in several research projects focusing on the Arctic fox, as well as intensive conservation actions aiming to improve the status of the population. The distribution of the red fox overlaps with that of the Arctic fox, but the red fox is less abundant at high altitudes and where primary productivity is low. The abundance of red foxes in the mountain tundra appears to have increased since the 19th century
(Linnell et al. 1999; Dalerum et al. 2002; Frafjord 2003; Killengreen et al. 2007; Selås \& Vik 2007).

\section{Russia, Southern Yamal}

In the Siberian Arctic, including the Yamal Peninsula, Arctic foxes are common. During the Soviet period they were actively trapped for fur, but in the beginning of the 1990s the fur trade collapsed and at present only few Arctic foxes are hunted by local people. Arctic and red foxes were studied at the Erkuta monitoring site, an erect shrub tundra region on southern Yamal $\left(68^{\circ}\right.$ $\mathrm{N}, 69^{\circ} \mathrm{E}$; e.g., Sokolova et al. 2014). The site is located approximately $150 \mathrm{~km}$ north of the limit of the larch (Larix sibirica) forest tundra zone and $110 \mathrm{~km}$ north of the isolated forested valley of the Shuch'ya River. The Arctic fox is common in the area, while the red fox is present but rare. However, red foxes breed regularly in the Shuch'ya valley (S. Mechnikova, pers. comm.). The monitoring project at Erkuta addresses the dynamics of the vertebrate tundra food web with a focus on impacts of climate change. Gathering of information started with limited empirical observations in 1989, and regular fieldwork and data collection began in 1998. Systematic surveys of fox dens were initiated in 2007. 


\section{North America}

The Arctic fox is abundant in North America and the overall population probably ranges in the tens of thousands of individuals (CAFF 2013). From the 1920 s to the mid-1970s, Arctic fox fur was a very important asset traded by Inuit from Canada and Alaska to secure cash and other valuable goods (Sawtell 2005). Currently, few hunters still trap foxes and trapping is no longer a major economic activity. The effects of the heavy trapping period followed by a virtual cessation of trapping on Arctic fox populations are unknown. On a large scale, changes in the relative abundance of red and Arctic fox in the Canadian Arctic have been studied through analyses of historical fur harvest records from the Hudson's Bay Company Archives spanning 1926-1950 (Gallant 2014). On smaller scales, Arctic and red foxes were studied in three areas: Greater Prudhoe Bay (Alaska), North Yukon (Canada) and Bylot Island (Canada).

Greater Prudhoe Bay $\left(70^{\circ} \mathrm{N}, 148^{\circ} \mathrm{W}\right)$ is located in the central Arctic Coastal Plain between the Brooks Range (southern limit) and the Beaufort Sea (northern limit). This area is generally flat tundra with few streams and rivers, but thousands of ponds and small lakes (Walker 1985). The Arctic fox is common in the area, while before the 1990s, red foxes were confined to the river drainages and the foothills (Burgess 2000; Stickney et al. 2014; ABR, Inc unpubl. data). BP Exploration (Alaska) funded a regional study on the Arctic fox population in the early 1990s (Burgess \& Banyas 1993; Ballard et al. 2000), and BP funded a smaller study in 2005-2014 (Stickney et al. 2014; Bishop \& Streever 2016).

Both red and Arctic foxes occur and reproduce in the coastal plain of Yukon, Canada (Smits \& Slough 1993; Gallant et al. 2012; Gallant 2014). The two species were studied in the Yukon coastal plain, mostly in Ivvavik National Park and Herschel Island Territorial Park. The region has an Arctic climate and Yukon's coastal plain is a band of flat Arctic tundra habitat (see further Gallant et al. 2012). Herschel Island is located approximately $2.5 \mathrm{~km}$ from the Yukon mainland. Fox den surveys were conducted during 13 summers in 1971-72, 1984-1990, 2003 and 2008-2010 (Gallant et al. 2012). In addition, 18 variables potentially indicative of den selection by Arctic and red foxes were measured in 2008-09 (Gallant et al. 2014).

Bylot Island, which is a part of Ivvavik National Park, is located at the northern tip of Baffin Island, Nunavut, in the Canadian High Arctic. The island is dominated by mountains and a large icecap except for a $1600 \mathrm{~km}^{2}$ South Plain. This portion of the island is covered by relatively lush tundra vegetation for the latitude. Snow typically covers the ground from late
September to mid-June. The mammalian predator guild is dominated by the Arctic fox and the stoat (Mustela erminea), but red foxes have been present in low numbers in the region since the 1950s (Gagnon \& Berteaux 2009). Arctic and red foxes are monitored since 1993 and about 110 dens covering approximately $600 \mathrm{~km}^{2}$ are surveyed annually (Cameron et al. 2011), with approximately 30 adults and 10-60 cubs trapped and marked annually.

\section{Results}

\section{Factors limiting red fox abundance and large- scale red fox expansions}

Red foxes are favoured by mild climate conditions, high resource availability and low levels of interspecific competition from larger carnivores (Fig. 1b). In Arctic and sub-Arctic Eurasia, red fox abundance decreases towards the Arctic and with increasing wolf (Canis lupus) abundance, but the latter relationship weakens in Arctic locations (Ehrich et al. 2016). In north boreal and alpine Sweden, snow depth has a negative effect on red fox abundance, while prey density (rodents, hares and grouse) and ungulate density have positive effects, suggesting that a high density of ungulates (moose and reindeer) is likely to favour red foxes through an increased availability of carrion (Carricondo-Sanchez et al. 2016). In Norway, the historic red fox expansion has been linked to increasing ungulate populations that could have increased the availability of carrion in winter (Selås \& Vik 2006). Although the increase of ungulates parallels recent increases in temperature, it is to a larger extent caused by changes in the management of wild and semidomestic ungulate species or the suppression of apex predators (Selås \& Vik 2006, 2007). The abundance of red fox in the Low-Arctic tundra of Varanger, which is located relatively close to the coast, is positively linked to the number of resident semi-domestic reindeer (Henden et al. 2014), providing firmer evidence for the red fox-ungulate connection. Red foxes expanded in the Canadian Arctic during 1926-1950 in relation to focal points of human activity (sedentary sites), not climate trends, which suggests that food subsidies rather than climate change were the main direct driver of changes to their distribution (Gallant 2014). In the Bylot area, red foxes thrive mostly around the village of Pond Inlet and are scarcer elsewhere (Berteaux et al. unpubl. data), supporting the above. Red fox expansion into the low-alpine tundra in Finnish Lapland took place during a long non-cyclic period of voles from the mid-1980s to around 2010 (Cornulier et al. 2013). During this period, the abundance of biggersized vole species such as field vole (Microtus agrestis) was low, but small agile forest species such as bank vole (Myodes glareolus) and red-backed vole (Myodes 
rutilus) remained common and their dynamics turned seasonal and non-cyclic (Henttonen 2000). Consequently, there were appreciable levels of vole prey every year, without any of the typical 'population crash years', i.e., years with very low prey abundance for predators, including red foxes. Consequently, there was a continuous influx of red foxes from the north boreal forests into the low alpine tundra (Henttonen et al. unpubl. data).

South of the Arctic, red fox abundance is positively associated with primary productivity, summer temperatures, human population density, cropland and young forest stages (Fig. 1b). These factors are assumed to be related to high prey availability, and in the case of human population density, access to anthropogenic food resources such as garbage and livestock (Kurki et al. 1998; Bartoń \& Zalewski 2007; Pasanen-Mortensen et al. 2013; PasanenMortensen \& Elmhagen 2015). Red fox abundance is negatively associated with severe winter conditions (Bartoń \& Zalewski 2007; Pasanen-Mortensen et al. 2013). In Eurasia, it is negatively associated with the larger Eurasian lynx (Lynx lynx; Elmhagen et al. 2010; Pasanen-Mortensen et al. 2013; Savola 2015), and in North America with the larger coyote (Canis latrans; Ripple et al. 2013; Newsome \& Ripple 2015).

Species expansions can occur through two not necessarily mutually exclusive processes: local demographic increases or geographic expansions where new areas become colonized. A relatively close relationship between the Holarctic lineage of red foxes in Eurasia and North America suggests gene flow between the two continents during the last glacial maximum and rapid expansion after the last Ice Age (Kutschera et al. 2013). However, Statham et al. (2014) used an extensive dataset to demonstrate strong divergence, which means that genetic exchange between the continents have been limited since the first colonization of North America. In a more recent time frame, the early 1900s, a red fox range expansion in North America from south-eastern regions to the Canadian Arctic Archipelago in the High Arctic was identified by anecdotal observations (Marsh 1938), reports and fur harvest records (Macpherson 1964), and local knowledge of Inuit trappers (Gagnon \& Berteaux 2009). This has also been supported by detailed analyses of fur harvest records specific to the period of range expansion (i.e., 1926-1950), which showed that there were two independent poleward range shifts in the eastern Canadian Arctic; one in the Canadian archipelago and the other on presentday continental Nunavut (Gallant 2014). Genetic analysis of red foxes in the Atlantic coastal plain has confirmed introduction of European red foxes into eastern USA in the 1800s, and most European haplotypes were found in urban-associated red fox populations (Kasprowicz et al. 2016). Nevertheless, established red fox populations in most parts of North America have been shown to be of native genetic origin (Statham et al. 2012). This includes red foxes at their northernmost expansion front at Bylot and Herschel islands (Berteaux et al. 2015), which are genetically related to neighbouring native populations. To date, genetic evidence therefore suggests that the northward red fox expansion in the North American Arctic can be attributed to native foxes (Statham et al. 2012; Berteaux et al. 2015). However, the findings from eastern USA suggest that introgression of European as well as fur farm haplotypes in North American red foxes needs further study, in particular in populations occupying habitats close to urban areas (Kasprowicz et al. 2016).

Red fox range expansion and population increase in the Fennoscandian tundra since the 19th century is evidenced by increasing abundance of red fox dens and excavations (Henttonen et al. unpubl. data), increasing hunting bags and anecdotal observations (Selås \& Vik 2007; Elmhagen et al. 2015), as well as genetic patterns. Genetic patterns in populations are characterized by the processes generating them, such as geographic range expansion, local demographic increases, or a combination of these. Fennoscandia was covered by inland ice during the last glacial maximum and genetic analyses reveal that red foxes colonized Fennoscandia from multiple glacial refugia (Edwards et al. 2012), and that the majority of tundra red foxes most likely originate from an easterly refugium such as Beringia (Wallén et al. unpubl. data). However, the colonization of the tundra is a more recent process. The Fennoscandian red fox population is connected by high and asymmetric dispersal, but no major genetic temporal shift has been detected, which indicates that the ongoing northern population increase is a combined effect of in situ demographic growth and immigration (Norén et al. 2015). Surrounding boreal areas thus function as sources that augment the alpine tundra population with colonizers from multiple directions (Norén et al. 2017).

\section{Concurrent changes in the ranges and population trends of Arctic and red foxes}

Red fox range expansion and Arctic fox range contraction have taken place in Fennoscandia, where red foxes expanded in the most productive habitats and where they are subsidized by human activities (Fig. 2). Arctic foxes dig dens in eskers and other sand formations. In Fennoscandia, where no permafrost destroys the excavations, high-quality dens have been used for (at least) hundreds of years. These dens have developed into large structures ('castles') that remain in the landscape despite low usage over the last century. Hence the present distribution of Arctic fox dens reveals the extent of the 
historical distribution of Arctic foxes. Den use patterns show that Arctic foxes are now restricted to areas at higher altitude within its former range, and that red foxes use Arctic fox dens that are located at lower altitudes and closer to the treeline (Linnell et al. 1999; Dalerum et al. 2002; Frafjord 2003). A high food niche overlap between the species, combined with their opportunistic feeding strategies, suggest that observed range shifts are not related to different prey preferences per se (Frafjord 1994, 2000; Elmhagen et al. 2002), but rather to an overall increase in food abundance which favours the red fox. Across Fennoscandia, the probability that Arctic foxes will use a den for breeding decreases with increased risk of red fox presence, the latter which is related to low altitude and high productivity (Herfindal et al. 2010). Arctic foxes are also less likely to use dens close to human infrastructure such as roads and cabins (Selås et al. 2010). In Varanger, where the alpine tundra meets the Arctic tundra, the red fox is now numerous because of the subsidizing effect of abundant carrion of semidomesticated reindeer (Killengreen et al. 2011; Killengreen et al. 2012; Henden et al. 2014). Dens where Arctic fox breeding ceased are characterized by a higher biomass of climate-sensitive plants, a higher abundance of passerines and birds of prey, and a higher frequency of unidentified fox scats (likely stemming from red fox), all of which are suggestive of red foxes now occupying the region's most productive areas (Killengreen et al. 2007).

In the low-altitude alpine tundra of Finnish Lapland, an initial increase in the number of red foxes was believed to have little impact on the Arctic fox (Kaikusalo \& Angerbjörn 1995). However, a few years later it was clear that a decline and extirpation of the Arctic fox coincided with the establishment and increased breeding of red fox (Fig. 2; Kaikusalo et al. 2000). A recent survey in the north-western part of this area (Henttonen et al. unpubl. data). shows that the number of new excavations by the red fox has increased rapidly since the late 1980s, and an extensive helicopter survey revealed 40 old Arctic fox den sites at a mean altitude of $671 \mathrm{~m}$ (SD $92 \mathrm{~m}$, range 540-890 m), and 137 red fox dens/excavations at a mean altitude of $639 \mathrm{~m}$ (SD $72 \mathrm{~m}$, range $470-870 \mathrm{~m}$ ). In practice, this constitutes a complete altitudinal overlap between the present red fox and the former Arctic fox ranges (Henttonen et al. unpubl. data). The last Arctic fox breeding in the area was in 1994. The red fox also occupies the entire former range of the Arctic fox in north-eastern Finnish Lapland, where alpine altitudes are even lower, and where the last breeding of the Arctic fox occurred in 1996.

Red fox population increase and concurrent Arctic fox decline was also observed in the Greater Prudhoe Bay area in Alaska (Fig. 2). In Prudhoe Bay, only one of 86 surveyed dens in a study area of $2681 \mathrm{~km}^{2}$ was occupied by red foxes in 1992 (Burgess \& Banyas 1993). In 2005-2014, between 31 and 48 dens were surveyed yearly (Stickney et al. 2014). In 2005, 2006 and 2008, Arctic fox dens outnumbered those of red foxes. In 2009, there was an equal number of dens of both species, but from 2010 onward, red fox dens dominated and peaked at 15 natal dens in 2011, while Arctic fox natal dens were reduced to one to three active yearly. Of the 38 dens that were part of the original den inventory and used by Arctic foxes in the early 1990s, $47 \%$ became occupied by red foxes during the recent study, and once taken over, they did not revert to Arctic fox occupation (Stickney et al. 2014). Anecdotal observations collected in an oilfield area adjacent to the Greater Prudhoe Bay area indicated that red foxes had become more common there, too, since the mid-1990s, but also that they had not yet displaced Arctic foxes from the area of oilfield infrastructure (ABR, Inc. unpubl. data). These two oilfields differ considerably in the density of development. The older Prudhoe Bay field has a higher density of facilities and human activities and more camps, and therefore the availability of anthropogenic foods is potentially higher there. A study of Arctic fox diets found that foxes in Prudhoe Bay were more reliant on anthropogenic foods compared to those in the more remote National Petroleum Reserve in Alaska (Lehner 2012). A recent comparative study in Prudhoe Bay showed that red foxes had a higher dependency on anthropogenic foods than Arctic foxes (Savory et al. 2014).

In parts of Fennoscandia, the Arctic fox increased locally following the implementation of a conservation programme in 1999-2001 (Fig. 2). The programme implicated a two-pronged strategy: red fox culling and supplemental feeding. Both actions had a positive effect on the number of Arctic fox litters born. In two areas where intense management actions were carried out (Helags and Borgafjäll), the Arctic fox breeding populations increased by up to $200 \%$ per 3-4 years, i.e., the span between peaks in the rodent cycle (Angerbjörn et al. 2013). The breeding Arctic fox population in a third area (Vindelfjällen) showed a similar rate of increase after conservation actions intensified around 2010 (A. Angerbjörn unpubl. data). In Finnmark in northern Norway, Arctic foxes used larger parts of the area where red foxes were culled, showing that the former could recolonize the tundra with the help of red fox control (Hamel et al. 2013). However, in northernmost Finnish Lapland, red fox culling has been implemented within the former Arctic fox breeding area since 1999 without Arctic fox recolonization. Depending on the lemming and vole fluctuations, up to 500 red foxes have been culled yearly in an 
area with 60 known former Arctic fox den sites during the culling period in January-March. These areas are either at lower altitudes or in more southern latitudes than the areas where Arctic foxes increased following red fox culling.

Further evidence of the capacity of red fox to displace Arctic fox comes from Bailey (1992), who used the former as a biological control agent against Arctic foxes. Arctic foxes were introduced to some of the Aleutian Islands in Alaska before 1930. Because of negative impacts on the native bird fauna, sterile red foxes were introduced to two islands in 1983 and 1984. Follow-up surveys suggested that the number of Arctic foxes declined to extinction in the following years, while red foxes remained present (Bailey 1992).

\section{Arctic and red fox interactions where Arctic fox populations are stable}

In three study areas - southern Yamal, northern Yukon and Bylot Island - red foxes occurred without any indications of Arctic fox range contraction or decline, but interactions between Arctic and red foxes were observed (Fig. 2).

In Erkuta, southern Yamal, den surveys from 2007 to 2015 revealed that the number of Arctic fox natal dens remained stable over time (Ehrich et al. unpubl. data). The first red fox observation occurred in 1989 on the banks of the Erkuta River (V. Shtro, pers. comm.). Local Nenets people only occasionally shoot red foxes in winter. During summer fieldwork in 1999-2015, red foxes were observed only a few times, although two individuals were present in 2007 (Rodnikova et al. 2011). The first red fox litters were documented in 2014 in two dens with at least six cubs each (Sokolov et al. 2016). Overall, red fox presence seemingly increased in Erkuta, but the region remains dominated by Arctic fox. Erkuta is intensely used for reindeer herding, and bad winters with high reindeer mortality likely subsidized red foxes. Such winters preceded the summers of 2007 and 2014, when most red foxes were observed and when they first bred in the area, respectively (Bartsch et al. 2010; Sokolov et al. 2016).

The northern Yukon, where red foxes established more than 100 years ago (Hooper 1853; Nagy 1988), is located in the area which sustained the most intense warming in North America over the last four decades (Hansen et al. 2006) and experienced low and diminishing levels of anthropogenic activity. A comparison of recent (2008-2010) survey results with those from previous surveys performed in 1971-72 (Ruttan 1974; Ruttan \& Wooley 1974), 1984-1990 (Smits \& Slough 1993) and 2003 (D. Cooley unpubl. data) showed that climate warming did not alter the competitive balance between the two species, as evidenced by a relatively stable proportion of dens occupied by the two species. Arctic foxes are still numerically dominant and the geographical extent of red fox in northern Yukon even contracted significantly (Gallant et al. 2012).

The red fox arrived in the Bylot Island area during 1947-48 (Macpherson 1964; Gagnon \& Berteaux 2009), but the first scientific mention of a red fox on Bylot dates from 1977 (Kempf et al. 1978). Intensive monitoring of the two species indicates that Arctic foxes still largely dominate the fox community (Gauthier et al. 2013), with about $98 \%$ of fox captures being Arctic fox and 2\% red fox (Berteaux et al. 2017). However, one $50-\mathrm{km}^{2}$ section of the Bylot study area is now occupied by red foxes and Arctic foxes no longer reproduce there (Berteaux et al. unpubl. data).

In addition to papers from our study areas, we found one study which analysed den use of Arctic foxes with a comment on red foxes (Anthony 1996). The study was carried out in the Yukon-Kuskokwim delta in Alaska. The author noted that red foxes rarely used dens in the area, although the habitat was seemingly suitable. He suggested that extensive hunting of red foxes in winter might keep red fox numbers at a level where competition with Arctic foxes was insignificant (Anthony 1996).

\section{Effects of interference competition posed by red fox on Arctic fox mortality, reproduction and behaviour}

The red fox can kill and sometimes also consume Arctic foxes. Pamperin et al. (2006) reported an instance of interspecific killing of an adult Arctic fox by a red fox in Prudhoe Bay. Red foxes have been observed killing and/or preying on Arctic fox cubs in Fennoscandia and Prudhoe Bay (Fig. 2; Tannerfeldt et al. 2002; Stickney et al. 2014). In Varanger, red foxes culled within the Arctic fox conservation programme undergo necropsy. So far, three of 670 red fox stomachs have had remains of Arctic foxes, and all three cases stemmed from winters with apparently little food resources for foxes (S. T. Killengreen unpubl. data). On Bylot Island, Arctic fox carcasses are regularly found in the area occupied by red foxes, and anecdotal observations suggest Arctic fox killing by red fox (Berteaux et al. unpubl. data).

In all study areas, red foxes have been documented to exclude Arctic foxes from resources such as breeding dens, space and carrion, and interference competition incurred by Arctic fox can lead to behaviours that negatively impact their reproductive success (Fig. 2). In Fennoscandia, red fox presence can prevent Arctic foxes from using space and food resources such as ungulate carrion (Killengreen et al. 2012; Hamel et al. 2013). However, one study found no difference in the 
habitat use of the two species in winter but rather that Arctic foxes retreated to habitats at higher altitudes and farther from the tree-line in summer, which suggests that Arctic fox avoidance of red foxes is more pronounced when their cubs are young (Dalén et al. 2004). Arctic fox avoidance of red fox territories in summer is supported by a study showing that generally preferred dens of high quality were used less often by breeding Arctic foxes in years when these dens were located within reach of dens where red foxes were breeding. In the rare cases when Arctic foxes did breed close to a red fox den, the Arctic foxes often moved after one or two cubs were killed by red foxes (Tannerfeldt et al. 2002). In Yamal, interference between Arctic and red foxes was first described in 2007, when a red fox was seen intruding on an Arctic fox breeding den (Rodnikova et al. 2011). The Arctic foxes abandoned the den after the incident, and the cubs were not seen again despite searches around the den and in neighbouring ones. In Prudhoe Bay, the distance between natal dens of Arctic and red foxes was greater than that between natal dens belonging to the same species, suggesting avoidance of red fox denning territories by Arctic foxes. Red foxes also displaced Arctic foxes from dens closest to anthropogenic facilities (Stickney et al. 2014). In northern Yukon, red foxes displace Arctic foxes from dens in prey-rich habitats, as red foxes use dens located in habitats with more potential prey in spring, while Arctic foxes select those providing good refuge from predators (Gallant et al. 2014).

Population simulations using Fennoscandian data suggest that observed levels of Arctic fox exclusion from breeding dens by a relatively low number of red foxes would have been sufficient to cause an observed decline in a local Arctic fox population (Shirley et al. 2009). In 2001-2011 Arctic fox weaning success, i.e., the number of Arctic fox pairs established in the mating season which also weaned a litter, was 50\% lower in an area with little red fox culling compared to areas with intense red fox culling. Although the mechanism has not been demonstrated, a potential reason is that high levels of interactions with red fox lowers the reproductive success of Arctic fox (Meijer et al. 2013). In Finnish Lapland, voles commonly occur in the low alpine zone, while lemmings occur throughout the alpine zone but their dynamics are periodically irregular without high abundance peaks (Henttonen \& Kaikusalo 1993; Angerbjörn et al. 2001). During periods of lemming absence, Arctic foxes could previously utilize the more regularly fluctuating voles in the low alpine zone, but this area is denied to them after the red fox expansion. Consequently, Arctic foxes depend on less predictable and more infrequent lemming peaks at higher altitudes (Henttonen et al. unpubl. data).
This increased dependence on lemmings, which could negatively impact Arctic fox reproductive success, could also appear in other parts of Fennoscandia (Elmhagen et al. 2002).

\section{Discussion}

Since Hersteinsson \& Macdonald published their pioneering article in 1992, accumulating research confirmed its general hypothesis: the red fox's northern distribution limit is determined by the availability of food resources, whereas the Arctic fox's southern distribution limit is determined, through interspecific competition, by the abundance of the red fox. Red foxes are physically dominant over Arctic foxes, and when red fox populations reach ecologically effective densities, they can cause Arctic fox decline and/or competitive exclusion. Hersteinsson \& Macdonald proposed that climate determines food availability, and hence that climate warming ultimately can cause Arctic fox decline. This hypothesis appears to be partly supported in Fennoscandia, where the Arctic fox has retreated primarily from locations at low altitudes, where primary productivity and the abundance of prey such as passerine birds is relatively high (Elmhagen et al. 2002; Herfindal et al. 2010; Killengreen et al. 2011). In addition, the red fox appears to have benefited from anthropogenic factors such as human infrastructure and changes in ungulate management practices (Selås \& Vik 2006; Selås et al. 2010; Henden et al. 2014). Although climate change and changes in human activity may sometimes coincide, recent studies suggest that anthropogenic subsidies constitute an alternative ultimate factor driving red fox expansions (Stickney et al. 2014; Gallant 2014). Thus, red fox populations may establish north of the distribution limit determined by climate-imposed resource levels. This means that climate warming may not have been the only driver of the dynamics of the two species during the last century (Gallant 2014). These findings echo Hersteinsson \& Macdonald's discussion, which showed that they were mindful of the dangers of inferring causation from correlation, as they recognized that changes other than climate warming had occurred during their study period, including human settlements (Fig. 2).

Regarding the impact of climate, Hersteinsson \& Macdonald (1992) assumed a cascading bottom-up response where climate warming leads to increases in both primary and secondary productivity. However, although there are indications that climate warming implies higher primary productivity in tundra (increased plant biomass/'Arctic greening'), this will not affect foxes positively unless it is accompanied by higher secondary productivity; i.e., increased abundance of herbivores serving as prey. Presently 
the evidence is rather the opposite (CAFF 2013). The population cycles of small rodents have been dampened, at least temporarily, in several places in the boreal, alpine and Arctic biomes. The same regards herbivorous birds, and some of the largest herds of wild reindeer and caribou have plummeted. Indeed, most cases of increasing populations of ungulates (semi-domestic reindeer in Eurasia) and herbivorous birds (Arctic geese in North America) have an anthropogenic cause largely independent of climate change (CAFF 2013). Alternatively, however, if low prey availability during the low phase of the rodent cycle has a strong limiting effect on red fox populations, red foxes might be favoured by dampened population cycles. In the Finnish low-alpine tundra, the period of dampening concerned only some species in the rodent community, and the changed dynamics implied that some vole species were moderately available all years. This could have had a positive effect on the red fox, as suggested by the increasing red fox numbers during this period (Henttonen 2000; Henttonen et al. unpubl. data). Shrub advance in Arctic Alaska has also been suggested as the most likely driver of a recent establishment of snowshoe hares (Lepus americanus) in riparian corridors on the North Slope (Tape et al. 2016). As the shrub line continues to advance northward, this would also increase the size of habitat patches that favour red foxes. To summarize, we need to know more on linkages between primary and secondary productivity in a context of climate change (Fig. 1b).

In addition to climate warming, Hersteinsson \& Macdonald (1992) list a number of factors which could affect fox distributions and population trends through changes in resource abundance and accessibility, including human settlements, livestock husbandry and forestry. Our review shows support for all these factors and some additional ones, with new insight suggesting that carrion from semi-domesticated reindeer are potentially important for red foxes (Killengreen et al. 2011; Henden et al. 2014; Sokolov et al. 2016). The extent to which semidomesticated reindeer contributes subsidies to red foxes may, however, vary with local management regimes. In Fennoscandia, for example, carrion availability has increased in Varanger (Henden et al. 2014), while it has been declining for decades in Finnish Lapland, firstly, because wolves have been absent (Kaczensky et al. 2013), and secondly, because all reindeer are semi-domesticated and reindeer management in Finnish Lapland now includes widespread supplementary feeding in winter (Turunen \& Vuojala-Magga 2014). Consequently, starvation episodes during harsh snow conditions are minimized. Recent findings also highlight that red foxes can take advantage of anthropogenic infrastructure in tundra habitat, e.g., the oilfield infrastructure in Prudhoe Bay (Stickney et al. 2014). This very local effect agrees with Gallant et al. (2012), suggesting that climate change has not generally increased secondary productivity in the Arctic to the level needed to support red foxes away from areas of human habitation. Similarly, changes in species distribution patterns and population trends in northern Sweden over the last century suggest that expanding or increasing southern species were favoured by several factors; climate warming as well as land-use change and anthropogenic infrastructure (Elmhagen et al. 2015). The latter subsidizing factors can create suitable habitat patches that function as red fox refugia during harsh periods, in the tundra or neighbouring ecosystems, increasing the temporal connectivity and stability of expanding red fox populations (Henden et al. 2010; Killengreen et al. 2011, Killengreen et al. 2012; Elmhagen et al. 2015). Similar processes may also favour other expanding carnivore species. For example, it has been suggested that coyote expansion in North America was facilitated by anthropogenic land use and food subsidies (Ripple et al. 2013).

Classic ecological theory suggests that bottom-up cascades interact with top-down forces, and that topdown regimes should change with bioclimatic conditions (Oksanen \& Oksanen 2000). Accordingly, predator limitation of herbivores strengthens at lower latitudes within the Arctic tundra. Small-to-medium-sized herbivores are more strongly limited by predation than large herbivores are, indicating that the latter to some extent escape limitation by large carnivores (Legagneux et al. 2014). Similarly, the strength of the negative association between wolf and red fox densities in Arctic to sub-Arctic Eurasia decreases towards the Arctic (Ehrich et al. 2016). Large carnivores are generally rare in the tundra (CAFF 2013), which suggest they may not reach ecologically effective densities throughout this biome. Contrastingly, in more productive ecosystems, large carnivores can function as top predators, suppressing both ungulates and smaller mesopredators (Ripple et al. 2014). The classification of a species as top predator or mesopredator is context dependent, i. e., a mesopredator is a mid-ranked predator in a food web, independent of its size or taxonomy. Hence a species may function as a top predator in some ecosystems, but as a mesopredator in others (Prugh et al. 2009). In the northernmost parts of its range and on some Arctic islands, the Arctic fox is the only terrestrial predator or the largest mammalian predator (CAFF 2013), suggesting it could function as a top predator. In the absence of limitation from other carnivores (Oksanen \& Oksanen 2000), bottom-up resource cascades should then favour the Arctic fox. This can be seen in Iceland, where the Arctic fox population appears to benefit from warmer 
temperatures and an associated increase in prey availability since the 1970s (Hersteinsson et al. 2009; Pálsson et al. 2016). In contrast, and as proposed by Hersteinsson \& Macdonald (1992), this review suggests that the negative effect of interspecific competition outweighs the positive effect of higher food availability in locations where red foxes reach ecologically effective densities. The Arctic fox might therefore be seen as a top predator which can be turned into a mesopredator in relation to expanding populations of red foxes and other larger carnivores.

The impact of climate change on ecosystems is notoriously nonlinear and this may give rise to surprises in terms of new transient ecosystems states. That large parts of the boreal zone are experiencing reduced primary productivity along with climate warming (Sturm 2010), and the most recent observations that parts of the Arctic tundra are experiencing similar trends (Epstein et al. 2015), call for cautions about making naive short-term projections. However, in the very long run, climate warming may be predicted to increase the productivity of temperaturelimited ecosystems and strengthen top-down predation effects (Legagneux et al. 2014). This would lead to a shift towards a boreal species composition, where the Arctic fox is excluded from the predator guild.

\section{Conclusion}

MacArthur (1972) proposed that abiotic factors such as climate determine the geographical distribution of species, but distribution limits at the warm margin in particular should also be determined by competition. Hersteinsson \& Macdonald (1992) specified the hypothesis to fox species in the Arctic and framed it in an early climate change context. Drawing from the research carried out in their footsteps, we conclude that the northern distribution pattern of the red fox is determined either by resource availability or climate conditions, as these key limiting factors do not always covary, while the southern distribution pattern of the Arctic fox is determined by competition with the red fox. Although individual red foxes dominate individual Arctic foxes, Arctic fox populations will be affected only when the number of red foxes increases to ecologically effective densities. This involves two processes - geographic range expansion and local demographic increases - where the latter is sufficient in areas where red foxes are already present. Climate warming is predicted to increase human activities in the Arctic and sub-Arctic. For example, oilfields in Alaska and gas fields in Yamal are now expanding, and although companies have tried to reduce access to anthropogenic food sources in the newer fields, these disturbed systems may still favour red foxes if such mitigation efforts are not always successful. We therefore suggest that synergies between anthropogenically derived resource subsidies and climate warming will speed up Arctic ecosystem change as mobile species establish and increase to thrive in the refugia provided by human activity, with potential spill-over effects in surrounding ecosystems.

Twenty-five years after Hersteinsson \& Macdonald (1992) published their seminal paper, the Arctic fox-red fox model system still has a lot to contribute to our understanding of ongoing changes in communities and ecosystems of the North. In that respect, both the northern edge of the red fox distribution and the southern edge of the Arctic fox distribution offer potentially productive models to study intraguild competition, trophic interactions, community structure and ecosystem functioning. For example, we have only a partial understanding of the mechanisms linking ecosystem change to increased red fox abundance, particularly regarding the links between changes in climate, primary productivity and secondary productivity (Fig. 1b; Gauthier et al. 2013). It is also not clear how increased red fox abundance at tundra sites previously dominated by the Arctic fox might affect prey distribution and abundance. The management actions currently conducted in Fennoscandia (Angerbjörn et al. 2013) could be prudently designed to experimentally assess how resource availability and interspecific density dependence may interact. Furthermore, research on Arctic and red fox interactions and their consequences for Arctic fox demography and their common prey base is limited to a relatively small number of study sites. In particular, although research has been done at the altitudinal distribution limit of the Arctic fox in Fennoscandia, we lack information from sites along the latitudinal distribution limit of the Arctic fox, where this review suggests that Arctic and red fox interactions should be intense and potentially changing. Expanding the number of study sites could indicate at what densities red foxes become ecologically effective in suppressing Arctic foxes, and at what densities and ecological circumstances co-existence is possible. Long-term monitoring and detailed field studies of these competing species are ongoing in much of the circumpolar North (Berteaux et al. 2017) and future research should include coordinated efforts to test and refine hypotheses through comparative studies and multi-site experiments.

\section{Acknowledgements}

We dedicate this paper to the late Páll Hersteinsson (1951-2011), professor of mammal behaviour at the University of Iceland and member of the Arctic Fox Working Group within the IUCN Canid Specialist Group. Páll was a great naturalist with a very special 
eye for seeing things in a clear and distinct way. Through his early research as a PhD student, supervised by David Macdonald, he put the Arctic fox on the biological world map. Páll continued to work with Arctic fox research, management and conservation issues throughout his life. The Arctic fox studies by Páll were a source of inspiration to many scientists, especially the seminal paper that we address here. Páll Hersteinsson was also a story teller. Following the old Icelandic saga tradition, he told scientific stories, funny stories and long stories. We will try to keep his legacy alive and continue to tell about Páll in stories, both in scientific papers and in the saga tradition. We are also grateful to those that helped us with our research: fieldworkers, rangers, first nations and other residents of the North.

\section{Disclosure statement}

No potential conflict of interest was reported by the authors.

\section{References}

Angerbjörn A., Eide N.E., Dalén L., Elmhagen B., Hellström P., Ims R.A., Killengreen S., Landa A., Meijer T., Mela M., Niemimaa J., Norén K., Tannerfeldt M., Yoccoz N.G. \& Henttonen H. 2013. Carnivore conservation in practice: replicated management actions on a large spatial scale. Journal of Applied Ecology 50, 59-67.

Angerbjörn A., Tannerfeldt M. \& Lundberg H. 2001. Geographical and temporal patterns of lemming population dynamics in Fennoscandia. Ecography 24, 298-308.

Anthony R.M. 1996. Den use by Arctic foxes (Alopex lagopus) in a Subarctic region of western Alaska. Canadian Journal of Zoology 74, 627-631.

Bailey E.P. 1992. Red foxes, Vulpes vulpes, as biological control agents for introduced Arctic foxes, Alopex lagopus, on Alaskan islands. Canadian Field-Naturalist 106, 200-205.

Ballard W., Cronin M.S., Rodrigues R., Skoog R.O. \& Pollard R.H. 2000. Arctic fox, Alopex lagopus, den densities in the Prudhoe Bay oil field, Alaska. Canadian Field-Naturalist 114, 453-456.

Bartoń K.A. \& Zalewski A. 2007. Winter severity limits red fox populations in Eurasia. Global Ecology and Biogeography 16, 281-289.

Bartsch A., Kumpula T., Forbes B.C. \& Stammler F. 2010. Detection of snow surface thawing and refreezing in the Eurasian Arctic with QuikSCAT: implications for reindeer herding. Ecological Applications 20, 2346-2358.

Berteaux D., Gallant D., Sacks B.N. \& Statham M.J. 2015. Red foxes (Vulpes vulpes) at their expanding front in the Canadian Arctic have indigenous maternal ancestry. Polar Biology 38, 913-917.

Berteaux D., Thierry A.-M., Alisauskas R., Angerbjörn A., Buchel E., Ehrich D., Eide N.E., Flagstad Ø., Fuglei E., Gilg O., Goltsman M., Henttonen H., Ims R.A., Killengreen S.T., Kondratyev A., Kruckenberg H., Kulikova O., Landa A., Lang J., Menyushina I., Mikhnevich J., Norén K., Ollila T., Ovsyanikov N., Pokrovskaya L., Pokrovsky I., Rodnikova A., Roth J., Sabard B., Samelius G., Schmidt N.M., Sittler B., Sokolov A.A., Sokolova N.A., Stickney A., Unnsteinsdóttir E. R. \& White P. 2017. Harmonizing circumpolar monitoring of Arctic fox: benefits, opportunities, challenges, recommendations. Polar Research 36, article no. 2, doi: 10.1080/ 17518369.2017.1319602.

Bishop S.C. \& Streever B. (eds.) 2016. Long-term ecological monitoring in BP's North Slope oil fields through 2014. Anchorage: BP Exploration (Alaska) Inc.

Burgess R.M. 2000. Arctic fox. In J.C. Truett \& S.R. Johnson (eds.): The natural history of an Arctic oil field. Pp. 159-178. New York: Academic Press.

Burgess R.M. \& Banyas P.W. 1993. Inventory of Arctic fox dens in the Prudhoe Bay region, 1992. Anchorage: BP Exploration (Alaska) Inc.

CAFF 2013. Arctic biodiversity assessment. Status and trends in Arctic biodiversity. Akureyri: Conservation of Arctic Flora and Fauna.

Cameron C., Berteaux D. \& Dufresne F. 2011. Spatial variation in food availability predicts extrapair paternity in the Arctic fox. Behavioral Ecology 22, 1364-1373.

Carricondo-Sanchez D., Samelius G., Odden M. \& Willebrand T. 2016. Spatial and temporal variation in the distribution and abundance of red foxes in the tundra and taiga of northern Sweden. European Journal of Wildlife Research 62, 211-218.

Cornulier T., Yoccoz N.G., Bretagnolle V., Brommer J.E., Butet A., Ecke F., Elston D.E., Framstad E., Henttonen H., Hörnfeldt B., Huitu O., Imholt C., Ims R.A., Jacob J., Jedrzejewska B., Millon A., Petty S.J., Pietiäinen H., Tkadlec E., Zub K. \& Lambin X. 2013. Europe-wide dampening of population cycles in keystone herbivores. Science 340, 63-66.

Dalén L., Elmhagen B. \& Angerbjörn A. 2004. DNA analysis on fox faeces and competition induced niche shifts. Molecular Ecology 13, 2389-2392.

Dalerum F., Tannerfeldt M., Elmhagen B., Becker D. \& Angerbjörn A. 2002. Distribution, morphology and use of Arctic fox dens in Sweden. Wildlife Biology 8, 185-192.

Edwards C.J., Soulsbury C.D., Statham M.J., Ho S.Y.W., Wall D., Dolf G., Iossa G., Baker P.J., Harris S., Sacks B. N. \& Bradley D.G. 2012. Temporal genetic variation of the red fox, Vulpes vulpes, across western Europe and the British Isles. Quaternary Science Reviews 57, 95-104.

Ehrich D., Strømeng M.A. \& Killengreen S.T. 2016. Interference in the tundra predator guild studied using local ecological knowledge. Oecologia 180, 1147-1157.

Elger K., Opel T., Topp-Jørgensen E. \& Rasch M. 2012. INTERACT station catalogue. Aarhus: Aarhus University.

Elmhagen B., Kindberg J., Hellström P. \& Angerbjörn A. 2015. A boreal invasion in response to climate change? Range shifts and community effects in the borderland between forest and tundra. Ambio 44, 39-50.

Elmhagen B., Ludwig G., Rushton S.P., Helle P. \& Lindén H. 2010. Top predators, mesopredators and their prey: interference ecosystems along bioclimatic productivity gradients. Journal of Animal Ecology 79, 785-794.

Elmhagen B., Tannerfeldt M. \& Angerbjörn A. 2002. Foodniche overlap between Arctic and red foxes. Canadian Journal of Zoology 80, 1274-1285.

Epstein H.E., Bhatt U.S., Raynolds M.K., Walker D.A., Bieniek P.A., Tucker C.J., Pinzon J., Myers-Smith I.H., Forbes B.C., Macias-Fauria M., Boelman N.T. \& Sweet S. K. 2015. Tundra greenness. In M.O. Jeffries et al. (eds.): Arctic report card 2015. Arctic Program, National Atmospheric and Oceanic Administration. Accessed on the internet at http://www.arctic.noaa.gov/Report-Card/ Report-Card-2015 on 24 March 2016.

Frafjord K. 1994. Summer food-habits of Arctic foxes in the alpine region of southern Scandinavia, with a note 
on sympatric red foxes. Annales Zoologici Fennici 31, 111-116.

Frafjord K. 2000. Do Arctic and red foxes compete for food? Zeitschrift Fur Saugetierkunde - International Journal of Mammalian Biology 65, 350-359.

Frafjord K. 2003. Ecology and use of Arctic fox (Alopex lagopus) dens in Norway: tradition overtaken by interspecific competition? Biological Conservation 111, 445-453.

Gagnon C.A. \& Berteaux D. 2009. Integrating traditional ecological knowledge and ecological science: a question of scale. Ecology and Society 14, 19.

Gallant D. 2014. Le renard roux dans l'Arctique canadien: expansion géographique, changements climatiques et interactions avec le renard arctique. (The red fox in the Canadian Arctic: geographic expansion, climate change and interactions with the Arctic fox.) $\mathrm{PhD}$ Thesis, Université du Québec à Rimouski.

Gallant D., Reid D.G., Slough B.G. \& Berteaux D. 2014. Natal den selection by sympatric Arctic and red foxes on Herschel Island, Yukon, Canada. Polar Biology 37, 333-345.

Gallant D., Slough B.G., Reid D.G. \& Berteaux D. 2012. Arctic fox versus red fox in the warming Arctic: four decades of den surveys in north Yukon. Polar Biology 35, 1421-1431.

Gauthier G., Bety J., Cadieux M.-C., Legagneux P., Doiron M., Chevallier C., Lai S., Tarroux A. \& Berteaux D. 2013. Long-term monitoring at multiple trophic levels suggests heterogeneity in responses to climate change in the Canadian Arctic tundra. Philosophical Transactions of the Royal Society B 368, UNSP 20120482, doi: 10.1098/ rstb.2012.0482.

Hamel S., Killengreen S.T., Henden J.A., Yoccoz N.G. \& Ims R.A. 2013. Disentangling the importance of interspecific competition, food availability, and habitat in species occupancy: recolonization of the endangered Fennoscandian Arctic fox. Biological Conservation 160, 114-120.

Hansen J., Sato M., Ruedy R., Lo K., Lea D.W. \& MedinaElizade M. 2006. Global temperature change. Proceedings National Academy of Sciences of the United States of America 103, 14288-14293.

Henden J.-A., Ims R.A., Yoccoz N.G., Hellström P. \& Angerbjörn A. 2010. Strength of asymmetric competition between predators in food webs ruled by fluctuating prey: the case of foxes in tundra. Oikos 119, 27-34.

Henden J.-A., Stien A., Bårdsen B.J., Yoccoz N.G. \& Ims R. A. 2014. Community-wide mesocarnivore response to partial ungulate migration. Journal of Applied Ecology 51, 1525-1533.

Henttonen H. 2000. Long-term dynamics of the bank vole Clethrionomys glareolus at Pallasjärvi, northern Finnish taiga. In G. Bujalska \& L. Hansson (eds.): Bank vole biology: recent advances in the population biology of a model species. Polish Journal of Ecology 48 Supplement, 87-96.

Henttonen H. \& Kaikusalo A. 1993. Lemming movements. In N.C. Stenseth \& R.A. Ims (eds.): The biology of lemmings. Pp. 157-186. London: Academic Press.

Herfindal I., Linnell J.D.C., Elmhagen B., Andersen R., Eide N.E., Frafjord K., Henttonen H., Kaikusalo A., Mela M., Tannerfeldt M., Dalén L., Strand O., Landa A. \& Angerbjörn A. 2010. Population persistence in a landscape context: the case of endangered Arctic fox populations in Fennoscandia. Ecography 33, 932-941.

Hersteinsson P. 1984. The behavioural ecology of the Arctic fox (Alopex lagopus) in Iceland. PhD thesis, University of Oxford.
Hersteinsson P., Angerbjörn A., Frafjord K. \& Kaikusalo A. 1989. The Arctic fox in Fennoscandia and Iceland: management problems. Biological Conservation 49, 67-81.

Hersteinsson P. \& Macdonald D.W. 1982. Some comparisons between red and Arctic foxes, Vulpes vulpes and Alopex lagopus, as revealed by radio tracking. Symposium Zoological Society London 49, 259-289.

Hersteinsson P. \& Macdonald D.W. 1992. Interspecific competition and the geographical distribution of red and Arctic foxes Vulpes vulpes and Alopex lagopus. Oikos 64, 505-515.

Hersteinsson P., Yom-Tov Y. \& Geffen E. 2009. Effect of Sub-Polar Gyre, North Atlantic oscillation and ambient temperature on size and abundance in the Icelandic Arctic fox. Global Change Biology 15, 1423-1433.

Hooper W.H. 1853. Ten months among the tents of the Tuski, with incidents of an Arctic boat expedition in search of Sir John Franklin, as far as the Mackenzie River, and Cape Bathurst. London: John Murray.

Ims R.A., Killengreen S.T., Ehrich D., Flagstad Ø., Hamel S., Henden J.-A., Jensvoll I. \& Yoccoz N.G. 2017. Ecosystem drivers of an Arctic fox population at the western fringe of the Eurasian Arctic. Polar Research 36, article no. 8, doi: 10.1080/17518369.2017.1323621.

IPCC 2014. Climate change 2014: synthesis report. Geneva: Intergovernmental Panel on Climate Change.

IUCN 2009. Species and climate change. More than just polar bears. Gland: International Union for Conservation of Nature and Natural Resources.

Kaczensky P., Chapron G., von Arx M., Huber D., Andrén H. \& Linnell J.D.C. 2013. Status, management and distribution of large carnivores - bear, lynx, wolf \& wolverine - in Europe. Rome: Institute for Applied Ecology.

Kaikusalo A. \& Angerbjörn A. 1995. The Arctic fox population in Finnish Lapland during 30 years, 1964-93. Annales Zoologici Fennici 32, 69-77.

Kaikusalo A., Mela M. \& Henttonen H. 2000. Häviääkö naali Suomesta? (Will the Arctic fox become extinct in Finland?) Suomen Riista 46, 57-65.

Kamler J.F. \& Ballard W.B. 2002. A review of native and nonnative red foxes in North America. Wildlife Society Bullentin 30, 370-379.

Kasprowicz A.E., Statham M.J. \& Sacks B.N. 2016. Fate of the other redcoat: remnants of colonial British foxes in the eastern United States. Journal of Mammalogy 97, 298-309.

Kempf C., Harmel X., Sittler B. \& Piantanida A. (eds.) 1978. Notes géomorphologiques, ornithologiques et mammalogiques sur l'île Bylot et la région de Pond Inlet, Canada. Rapport d'expédition 1977. (Geomorphological, ornithological and mammalogical notes on Bylot Island and the Pond Inlet area, Canada. Expedition report 1977.) Scheltigheim, France: Groupe de Recherche en Écologie Arctique.

Killengreen S.T., Ims R.A., Yoccoz N.G., Bråthen K.A., Henden J.-A. \& Schott T. 2007. Structural characteristics of a low Arctic tundra ecosystem and the retreat of the Arctic fox. Biological Conservation 135, 459-472.

Killengreen S.T., Lecomte N., Ehrich D., Schott T., Yoccoz N.G. \& Ims R.A. 2011. The importance of marine vs. human-induced subsidies in the maintenance of an expanding mesocarnivore in the Arctic tundra. Journal of Animal Ecology 80, 1049-1060.

Killengreen S.T., Strømseng E., Yoccoz N.G. \& Ims R.A. 2012. How ecological neighbourhoods influence the structure of the scavenger guild in Low Arctic tundra. Diversity and Distributions 18, 563-574. 
Kurki S., Nikula A., Helle P. \& Lindén H. 1998. Abundances of red fox and pine marten in relation to the composition of boreal forest landscapes. Journal of Animal Ecology 67, 874-886.

Kutschera V.E., Lecomte N., Janke A., Selva N., Sokolov A. A., Haun T., Steyer K., Nowak C. \& Hailer F. 2013. A range-wide synthesis and timeline for phylogeographic events in the red fox (Vulpes vulpes). BMC Evolutionary Biology 13, 114.

Legagneux P., Gauthier G., Lecomte N., Schmidt N.M., Reid D., Cadieux M.-C., Berteaux D., Bêty J., Krebs C. J., Ims R.A., Yoccoz N.G., Morrison R.I.G., Leroux S.J., Loreau M. \& Gravel D. 2014. Arctic ecosystem structure and functioning shaped by climate and herbivore body size. Nature Climate Change 4, 379-383.

Lehner N.S. 2012. Arctic fox winter movement and diet in relation to industrial development on Alaska's North Slope. MS thesis, University of Alaska Fairbanks.

Linnell J.D.C., Strand O. \& Landa A. 1999. Use of dens by red Vulpes vulpes and Arctic Alopex lagopus foxes in alpine environments: can interspecific competition explain the non-recovery of Norwegian Arctic fox populations? Wildlife Biology 5, 167-176.

MacArthur R.H. 1972. Geographical ecology - patterns in the distribution of species. New York: Harper and Row.

Macpherson A.H. 1964. A northward range extension of the red fox in the eastern Canadian Arctic. Journal of Mammalogy 45, 138-140.

Marsh D.B. 1938. The influx of the red fox and its colour phases into the barren lands. Canadian Field-Naturalist 53, 60-61.

McBean G., Alekseev G., Chen D., Førland E., Fyfe J., Groisman P.Y., King R., Melling H., Vose R. \& Whitfield P.H. 2005. Arctic climate: past and present. In C. Symon et al. (eds.): Arctic climate impact assessment. Pp. 21-60. Cambridge: University Press.

Meijer T., Elmhagen B., Eide N.E. \& Angerbjörn A. 2013. Life history traits in a cyclic ecosystem - a field experiment of the Arctic fox. Oecologia 173, 439-447.

Nagy M.I. 1988. Caribou exploitation at the Trail River site (northern Yukon). PhD thesis, Simon Fraser University.

Newsome T.M. \& Ripple W.J. 2015. A continental scale trophic cascade from wolves through coyotes to foxes. Journal of Animal Ecology 84, 49-59.

Norén K., Angerbjörn A., Wallén J., Meijer T., Ågren E.O. \& Sacks B.N. 2017. Red foxes colonizing the tundra genetic analysis as a tool for population management. Conservation Genetics 18, 359-370.

Norén K., Statham M.J., Ågren E.O., Isomursu M., Flagstad O., Eide N.E., Björneboe T., Bech-Sanderhoff L. \& Sacks B.N. 2015. Genetic footprints reveal geographic patterns of expansion in Fennoscandian red foxes. Global Change Biology 21, 3299-3312.

Oksanen L. \& Oksanen T. 2000. The logic and realism of the hypothesis of exploitation ecosystems. American Naturalist 155, 703-723.

Pálsson S., Hersteinsson P., Unnsteinsdóttir E.R. \& Nielsen Ó.K. 2016. Population limitation in a non-cyclic Arctic fox population in a changing climate. Oecologia 180, 1147-1157.

Pamperin N.J., Follmann E.H. \& Petersen B. 2006. Interspecific killing of an Arctic fox by a red fox at Prudhoe Bay, Alaska. Arctic 59, 361-364.

Parmesan C. \& Yohe G. 2003. A globally coherent fingerprint of climate change impacts across natural systems. Nature 421, 37-42.
Pasanen-Mortensen M. \& Elmhagen B. 2015. Land cover effects on mesopredator abundance in the presence and absence of apex predators. Acta Oecologica 67, 40-48.

Pasanen-Mortensen M., Pyykönen M. \& Elmhagen B. 2013. Where lynx prevail, foxes will fail - limitation of a mesopredator in Eurasia. Global Ecology and Biogeography 22, 868-877.

Post E., Forchhammer M.C., Bret-Harte M.S., Callaghan T. V., Christensen T.R., Elberling B., Fox A.D., Gilg O., Hik D.S., Høye T.T., Ims R.A., Jeppesen E., Klein D.R., Madsen J., McGuire A.D., Rysgaard S., Schindler D.E., Stirling I., Tamstorf M.P., Tyler N.C.J., van der Wal R., Welker J., Wookey P.A., Schmidt N.M. \& Aastrup P. 2009. Ecological dynamics across the Arctic associated with recent climate change. Science 325, 1355-1358.

Prugh L.R., Stoner C.J., Epps C.W., Bean W.T., Ripple W.J., Laliberte A.S. \& Brashares J.S. 2009. The rise of the mesopredator. Bioscience 59, 779-791.

Ripple W.J., Estes J.A., Beschta R.L., Wilmers C.C., Ritchie E.G., Hebblewhite M., Berger J., Elmhagen B., Letnic M., Nelson M.P., Schmitz O.J., Smith D.W., Wallach A.D. \& Wirsing A.J. 2014. Status and ecological effects of the world's largest carnivores. Science 343, 1241484.

Ripple W.J., Wirsing A.J., Wilmers C.C. \& Letnic M. 2013. Widespread mesopredator effects after wolf extirpation. Biological Conservation 160, 70-79.

Rodnikova A., Ims R.A., Sokolov A., Skogstad G., Sokolov V., Shtro V. \& Fuglei E. 2011. Red fox takeover of Arctic fox breeding den: an observation from Yamal peninsula, Russia. Polar Biology 34, 1609-1614.

Ruttan R.A. 1974. Arctic fox on the north slope of the Yukon Territory, 1972. In R.A. Ruttant \& D.R. Wooley (eds.): Studies of furbearers associated with proposed pipeline routes in the Yukon and Northwest Territories. Arctic Gas Biological Report Series 9. Calgary: Canadian Arctic Gas Study Limited /Alaskan Arctic Gas Study Company.

Ruttan R.A. \& Wooley D.R. 1974. A study of furbearers associated with proposed pipeline routes in the Yukon Territory and Mackenzie River Valley, 1971. Arctic Gas Biological Report Series 8. Calgary: Canadian Arctic Gas Study Limited /Alaskan Arctic Gas Study Company.

Savola S. 2015. Voles and their trophic interactions in a changing landscape. $\mathrm{PhD}$ thesis, University of Helsinki.

Savory G.A., Hunter C.M., Wooller M.J. \& O’Brien D.M. 2014. Anthropogenic food use and diet overlap between red foxes (Vulpes vulpes) and Arctic foxes (Vulpes lagopus) in Prudhoe Bay, Alaska. Canadian Journal of Zoology 92, 657-663.

Sawtell S. 2005. Pond inlet. In M. Nuttall (ed.): Encyclopedia of the Arctic. P. 1682. New York: Routledge.

Selås V., Steinmo Johnsen B. \& Eide N.E. 2010. Arctic fox Vulpes lagopus den use in relation to altitude and human infrastructure. Wildlife Biology 16, 107-112.

Selås V. \& Vik J.O. 2006. Possible impact of snow depth and ungulate carcasses on red fox (Vulpes vulpes) populations in Norway, 1897-1976. Journal of Zoology 269, 299-308.

Selås V. \& Vik J.O. 2007. The Arctic fox Alopex lagopus in Fennoscandia: a victim of human-induced changes in interspecific competition and predation? Biodiversity and Conservation 16, 3575-3585.

Shirley M.D.F., Elmhagen B., Lurz P.W.W., Rushton S.P. \& Angerbjörn A. 2009. Modelling the spatial population dynamics of Arctic foxes: the effects of red foxes and microtine cycles. Canadian Journal of Zoology 87, 1170-1183.

Smits C.M.M. \& Slough B.G. 1993. Abundance and summer occupancy of Arctic fox, Alopex lagopus, and red fox, 
Vulpes vulpes, dens in the northern Yukon Territory, 1984-1990. Canadian Field Naturalist 107, 13-18.

Sokolov A.A., Sokolova N.A., Ims R.A., Brucker L. \& Ehrich D. 2016. Emergent rainy winter warm spells may promote boreal predator expansion into the Arctic. Arctic 69, 121-129.

Sokolova N.A., Sokolov A.A., Ims R.A., Skogstad G., Lecomte N., Sokolov V.A., Yoccoz N.G. \& Ehrich D. 2014. Small rodents in the shrub tundra of Yamal (Russia): density dependence in habitat use? Mammalian Biology 79, 306-312.

Statham M.J., Murdoch J., Janecka J., Aubry K.B., Edwards C.J., Soulsbury C.D., Berry O., Wang Z., Harrison D., Pearch M., Tomsett L., Chupasko J. \& Sacks B.N. 2014. Range-wide multilocus phylogeography of the red fox reveals ancient continental divergence, minimal genomic exchange and distinct demographic histories. Molecular Ecology 23, 4813-4830.

Statham M.J., Sacks B.N., Aubry K.A., Perrine J.D. \& Wisely S.M. 2012. The origin of recently established red fox populations in the contiguous United States: translocations or natural range expansions? Journal of Mammalogy 93, 52-65.
Stickney A.A., Obritschkewitsch T. \& Burgess R.M. 2014. Shifts in fox den occupancy in the greater Prudhoe Bay Area, Alaska. Arctic 67, 196-202.

Sturm M. 2010. Arctic plants feel the heat. Scientific American 302, 66-73.

Tannerfeldt M., Elmhagen B. \& Angerbjörn A. 2002. Exclusion by interference competition? The relationship between red and Arctic foxes. Oecologia 132, 213-220.

Tape K.D., Christie K., Carroll G. \& O’Donnell J.A. 2016. Novel wildlife in the Arctic: the influence of changing riparian ecosystems and shrub habitat expansion on snowshoe hares. Global Change Biology 22, 208-219.

Turunen M. \& Vuojala-Magga T. 2014. Past and present winter feeding of reindeer in Finnish Lapland: herders' adaptive learning of feeding practices. Arctic 67, 173-188.

Walker D.A. 1985. Vegetation and environmental gradients of the Prudhoe Bay region, Alaska. Report 85-14. Hanover: Cold Regions Research \& Engineering Laboratory.

Zhang Y., Wang X., Fraser R., Olthof I., Chen W., Mclennan D., Ponomarenko S. \& Wu W. 2013. Modelling and mapping climate change impacts on permafrost at high spatial resolution for an Arctic region with complex terrain. The Cryosphere 7, 1121-1137. 